\title{
Remittances and Educational Outcomes: A Regional Investigation for Moldova
}

\author{
Alessia Matano ${ }^{1}$ and Raul Ramos ${ }^{2}$
}

February 2016

\begin{abstract}
$^{3}$
This paper looks at the relationship between remittances and higher education in Moldovan regions. The objective is to test whether remittances are associated with an increase in the likelihood of attending higher education institutions by taking into account a possible disruptive effect of migration and looking for regional differences in this relationship. Findings show that, on average, remittances are associated with a 5.4 percentage point increase in the likelihood that young individuals will pursue higher education. Nonetheless, this result is widely heterogeneous across regions.
\end{abstract}

JEL Classification: I21, F22, F24, R10.

Keywords: Migration, Remittances, Education, Regional Heterogeneity, Urban Areas.

${ }^{1}$ A. Matano, AQR-IREA, Universitat de Barcelona. Email: amatano@ub.edu. Corresponding author.

2 R. Ramos, AQR-IREA, Universitat de Barcelona.

${ }^{3}$ We deeply aknowledge the Kiel Institute for the World Economy for providing the database. The research leading to these results has received funding from the European Community's Seventh Framework Programme (FP7/2010-2.2-1) under grant agreement n. 266834. We also express our gratitude for the support received from Spain's Ministerio de Ciencia e Innovación (VI Plan Nacional de Investigación Científica, Desarrollo e Innovación Tecnológica 2008-2011) through the action ECO2013-41022-R. 


\section{Introduction and objectives}

The relationship between remittances and educational outcomes has been widely investigated in the empirical literature. Previous research has identified two channels through which remittances can increase the education level in origin countries. One channel is direct: remittances increase available income that can be spent on education. The other channel is indirect: remittances help families to buy better housing or create businesses that enhance the general welfare of the state, which can be translated to a different use of resources by the government in the direction of education facilities (schools, etc.) (Kanaiapuni and Donato 1999). At the empirical level, the positive relationship between remittances and education is confirmed (Zhunio et al. 2012; Edwards and Ureta 2003, Lopez-Cordova 2005, Hanson and Woodroff 2003, Mansour et al. 2011, Amuedo-Dorantes and Pozo 2010, Bansak and Chesum 2009, Calero et al. 2009). Nonetheless, the literature has also pointed out the possibility of a negative impact of migration on educational outcomes in origin countries due to a family disruption effect (McKenzie and Rapoport 2006; Amuedo-Dorantes and Pozo 2010). In fact, emigration is often felt by those left behind as a kind of "loss", which brings significant changes in social networks and relationships (Marchetti-Mercer 2012). When considering this effect, the literature has pointed out a different outcome of the relationship between remittances and education. In particular, Amuedo-Dorantes and Pozo (2010) try to disentangle the direct effect of migration from the impact of remittances on education. They consider two groups of household members, distinguished by whether or not their family had a migrant abroad. Their findings show that when families with a migrant abroad are included in the analysis, the impact of remittances on education is no longer significant. Consideration of this aspect has been scarce in the empirical literature, since the availability of data on remittances for families not having a migrant abroad is limited.

Furthermore, this literature generally takes into account the impact of remittances on education at a national level, not considering the possibility of heterogeneity of this impact across regions within a country. However, if regions within a country differ in their degree of economic development or in other economic features, as well as migration patterns, it is likely that the relationship between remittances and education will be heterogeneous across regions. To the best of our knowledge, this issue has not been explored in the literature until now.

The contribution of this article to the empirical literature is twofold. First, it analyses the relationship between the receipt of remittances and attendance at higher education institutions, taking into account the direct impact of migration on this relationship. This 
analysis is possible thanks to the availability of household data that distinguish between individuals with a family member abroad from those who do not. The focus is on Moldova, which represents a suitable case study for this investigation. In fact, compared to previous studies, Moldova is interesting since it is a country where temporary migration is more common than permanent migration, unlike traditional migrating countries like Mexico, Ecuador, or the Dominican Republic (Piracha and Saraogi 2012) ${ }^{4}$. Also, it is a country characterised by a high share of migration in the economically active population and where remittances constitute around 30\% of the Gross Domestic Product (GDP). ${ }^{5}$ Therefore, by looking at Moldova the analysis can contribute to further characterising the aspects affecting this relationship, i.e., to understand whether a negative disruptive effect arises because of migration itself or if it is likely to be generated when migration is considered to be permanent. ${ }^{6}$

Second, this paper analyses the relationship between remittances and education from a regional perspective. In particular, the empirical analysis investigates whether this relationship is heterogeneous across regions and points out characteristics that might affect the relationship between remittances and education. Again, Moldova is an interesting case study in this context, since it is characterised by a strong degree of territorial decentralisation and regional differences. Further, the association between remittances and education across urban and non-urban areas is also addressed.

The analysis uses household data from the 2006-2008 CBSAXA Moldovan Household Survey provided by the Kiel Institute. The unit of analysis is household members in Moldova interviewed for the 2008 survey, and the variables of interest are attendance at higher education institutions of household members and a dichotomous variable indicating the remittance receipt status of the households.

As for the regional dimension and according to the official statistics of Moldova, the country is formed by one main municipality and capital, Chisinau, plus 32 rayons/districts,

\footnotetext{
${ }^{4}$ This is also confirmed in the data: among the migrants already abroad or who came back in 2007 or 2008, more than 50\% left Moldova for the first time only after 2004. Moreover, regarding the pattern of migration, $49 \%$ of these migrants report that they go back and forth on a regular basis, $17 \%$ report that they live in Moldova most of the time, while only $34 \%$ declare to be permanent migrants. It is nonetheless important to stress that these percentages include a small fraction of irregular migration, around $18 \%$, which is more permanent in character (51\% declare a permanent migration status).

5 In the case of Moldova, there are summary reports on migrants' characteristics and remittances based on the CBS_AXA household data (Lücke et al. 2007; Lücke et al. 2009). Also, Siegel and Lücke (2013) explain the choice of transfer channel for remittances in Moldova, while Pinger (2010) analyses the behaviour in terms of remittances between temporary and permanent migrants. Finally, Piracha and Saraogi (2015) look at the impact of remittances on the migration intentions of the left-behind.

${ }^{6}$ Since the paper focuses on household members between the ages of 15 and 26, the possible lack of evidence of a disruptive effect of migration does not imply that there is not a disruptive effect at work in migrants' households. In fact, it might be that this effect is present for other age groups.
} 
classified as belonging to the North, Centre, and South, and the autonomous territorial unit of Gagauzia.

The analysis makes use of probit methodologies in order to estimate the relationship between the likelihood of attending a higher education institution-from not compulsory secondary school to university education - and receipt of remittances. Past remittances (as recorded in the 2006 survey wave) are used as the main independent variable to control for issues related to the simultaneous determination of remittances and education decisions and to give a time lag between the receipt of remittances and the investment in education. Nonetheless, it is possible that unobserved factors that can affect both remittances and education decisions might remain, even by using past remittances; thus, the paper does not claim casual effect. The results show that being a member of a family receiving remittances is associated with a 5.4 percentage point increase in the probability that young family members (between ages 15 and 26) ${ }^{7}$ will attend a higher education institution. Moreover, there is no significant evidence of a disruptive effect due to migration. This can be explained by the prevalence of temporary migration in Moldova, which reduces the likelihood of a negative association between migration and education. Also, it is plausible that other age groups are more likely to feel the disruptive effect of migration, such as very young individuals (age 15 and below), particularly when the migrant is the mother.

When taking into account the regional dimension, results show that the relationship between remittances and higher education is heterogeneous across regions. In particular, Chisinau is the region with the highest percentage of young members attending higher education institutions and where remittances are highly correlated with the probability of pursuing higher education. Conversely, the South is the region with the lowest rate of young members attending higher education institutions and where the interaction with remittances is significant and negative, pointing to a picture in which the association between remittances and higher education is significantly lower in the South compared to the other regions. The results for the other regions generally lie between these extremes. A possible explanation for this outcome might be related to the different economic performance and migration patterns of the regions in Moldova. In fact, the South is a relatively non-urban area, which largely relies on agriculture and is characterised by worse labour market conditions than the other regions. Also, its migrants generally go to Russia and Eastern Europe. On the other hand, Chisinau is the capital and the richest and most developed region, with a migration equally spread between Western and Eastern Europe, which may drive the high correlation detected (around 12 percentage points difference in

7 The age bracket of the sample has been selected considering the age after compulsory secondary education and the age by which most of students obtain a master's degree. 
higher education between members who receive remittances and those who do not). The North and the Centre are in an intermediate position, especially concerning their level of development. Migration from these regions is mostly directed toward Russia and Eastern Europe. Given the evidence of the relationship between remittances and education, this seems to suggest a certain degree of complementarity between the investment of remittances in education, regional economic performance, and the Western migration pattern.

Moreover, living in an urban area is generally associated with an increase in the probability of pursuing a high level of education, while the interaction between remittances and urban area dummies is not significant, pointing to no relevant correlation between remittances and education depending on the degree of urbanisation of the area of residence.

From a policy point of view, these findings suggest the promotion of policies aimed at both fostering remittances and stimulating regional development in order to better exploit the positive association between remittances and education. These outcomes also advise the need to take into account regional heterogeneity in the relationship between remittances and education when designing policies aimed at fostering education. They also point out the importance of possible regional heterogeneity in other countries that are similarly characterised by strong territorial differentiations.

The rest of the paper is organised as follows. Section 2 provides a description of the territorial aspects of Moldova. Section 3 describes the data and presents descriptive evidence from the sample data. Section 4 shows the empirical analysis. Section 5 concludes.

\section{Territorial Aspects of Moldova}

Moldova is a region characterised by a strong degree of territorial decentralisation and regional imbalances. According to the official statistics of Moldova, the country can be considered as formed by one main and more developed municipality, Chisinau, (the capital), 32 rayons/districts (classified as belonging to the North, Centre, and South), and the autonomous territorial unit of Gagauzia. ${ }^{8}$ According to the Biroul National de Statistica al Republicii Moldova, the regions are defined as follows: 1) Municipality of Chişinău; 2) North: Municipalities of Bălți, Briceni, Donduşeni, Drochia, Edineț, Făleşti, Floreşti, Glodeni, Ocnița, Rîşcani, Sîngerei, Soroca; 3) Centre: Municipalities of Anenii Noi, Călăraşi, Criuleni, Dubăsari, Hînceşti, Ialoveni, Nisporeni, Orhei, Rezina, Străşeni, Şoldăneşti,

\footnotetext{
${ }^{8}$ The territorial unit of Transnistria, which is also part of the country, is not available in the data. Also, it is worth noting that Balti is the second main important municipality of Moldova, and is included in the North by official statistics.
} 
Teleneşti, Ungheni; 4) South: Municipalities of Basarabeasca, Cahul, Cantemir, Căuşeni, Cimişlia, Leova, Ştefan Vodă, Taraclia; 5) UTA Găgăuzia. Figure 1 shows a picture of the territorial division of the country.

[Figure 1 around here]

These areas are characterised by different levels of density and urbanisation, labour market conditions, and economic activity. Data from official sources describe the territorial differentiation of the country. Table 1 shows descriptive statistics on total population, degree of urbanisation, density and labour market characteristics for the different regions of Moldova in 2011 (the first year of available territorial data).

[Table 1 around here]

The population is not homogeneously spread across the regions. In fact, most of the population resides in the North and the Centre, as well as in Chisinau (which is in the Centre part of the country), while fewer people live in the South and in the autonomous region of Gagauzia, where the population is mainly constituted by the Gagauzi, a Turkishspeaking ethnic minority. In terms of density, Chisinau has the highest ratio of inhabitants per squared $\mathrm{km}(1,381)$, followed by the North and the Centre. In terms of urban composition, Chisinau is a municipality that is almost entirely urban (91\%), followed by the Gagauzia and the North, comprising $40 \%$ and $35 \%$ of urban population respectively. In the Centre - excluding Chisinau - the percentage of urban population is $19 \%$, while in the South it is $25 \%$. Therefore, a first glance reveals that Moldova is very densely populated from the North to the Centre, with a heterogeneous degree of urbanisation across regions. As for labour market outcomes, the municipality of Chisinau as well as the North and the Centre have higher mean wages and employment rates compared to the rest of the country, pointing to better performance of these regions in terms of labour opportunities and outcomes.

A look to the incidence of economic activities across regions (Table 2) shows that agriculture is mainly concentrated in the South (18\%), while industry is mostly located in the region of Gagauzia (22\%) and, to a minor extent, in the other regions. Also, it is worth noting that the municipality of Chisinau is characterised by a strong service sector presence.

[Table 2 around here] 
Table 3 depicts the regional pattern of migration. It shows that migration shares and migrants' destination countries differ strongly across regions. In particular, the regions with the highest percentage of migrants is the South, where the percentage of household members with a member of the family abroad (or who came back in $2007 / 2008$ ) is $48 \%$, followed by the North, the Centre, and Gagauzia, where this percentage is around $40 \%$. Chisinau is the region with the lowest percentage, 19\%, suggesting a lower need for migration among household members living in the capital. When taking into account the destination countries of the migrants, it is worth noting that while for Chisinau migrants are spread almost equally between Western Europe and Eastern Europe/Russia, for the other regions there is a high prevalence of migration toward Eastern Europe/Russia, in particular for the North and Gagauzia, where the percentage of migrants going to Eastern Europe and Russia is around $80 \%$.

[Table 3 around here]

On the whole, this picture shows a certain regional heterogeneity in Moldova that can be summarised as follows. The municipality of Chisinau is densely populated and mostly urbanised, with better labour market conditions and oriented toward the industrial and service sectors. Its migration share is relatively low, with destination countries equally shared between Western and Eastern Europe/Russia. The North and the Centre are still quite densely populated and with good labour market conditions, with migration shares of around $40 \%$ mostly concentrated in Eastern Europe and Russia. However, in contrast to the North, the Centre is characterised by a high share of non-urban population. The South largely relies on agriculture and is characterised by the worst labour market conditions and low levels of urbanisation, with a relatively high percentage of migration (48\%) concentrated mostly in Eastern Europe and Russia (70\%). Finally, the autonomous region of Gagauzia is apart, with lower population density and wages, but quite urbanised and with significant presence of industry and agriculture. Its migration share is mostly directed to Eastern Europe and Russia or other countries outside the EU. This picture justifies the analysis of a possible different impact of remittances on education across regions, since the different characteristics of the regions might influence the likelihood of investing remittances in education. 


\section{Data description}

The analysis uses data from the 2006-2008 CBSAXA Moldovan Household Survey provided by the Kiel Institute, and the focus is on the wave for the year 2008, which provides information on the kind of education pursued by household members. The data for 2008 have 14,784 individual observations, which account for 3,915 households. The dataset is very rich, providing information about individual and household characteristics (age, gender, residence, size of the families, composition of families, etc.) as well as detailed information about the education level of the family members. There is also information on the presence of a migrant abroad and on the remittances receipt status of the households.

After some cleaning of the data, especially related to the education variable, ${ }^{9}$ the final sample of the analysis (which excludes the migrants abroad) includes 1,828 observations of household members between the ages of 15 and 26, with 26 as the age by which most students obtain a master degree. The empirical investigation makes use of all households in the sample, regardless of the presence of a migrant abroad, to shed light on the association between migration and higher education. It is worth noting that households without a migrant abroad may receive remittances from ex-members of their families or friends. ${ }^{10}$

The sample of reference and the main variables of the analysis are defined as follows. Households with a migrant abroad are those who either have a member of the family abroad or who has been abroad, but returned in 2007 or 2008. As for education, the focus is on data about higher education institutions attendance. The decision to focus on attendance rather than education attainment is motivated by the fact that the latter is likely to be influenced by the household history of remittance receipt (Amuedo-Dorantes and Pozo 2010), which is unavailable in the data. The education variable is originally coded in seven modalities (no formal education, primary education, gymnasium -lower secondary education-, secondary general education, secondary vocational education, secondary professional education, university). Since the interest of the paper is the relationship between remittances and the probability of attending a higher education institution (and due to the limited number of observations for the group of university graduates), this variable has been reclassified as a dichotomous variable, taking on a value of 1 for cases in

\footnotetext{
9 The following cases are excluded from the analysis: observations where information on education is missing; observations where the information on remittances or migrant status is missing; observations where the kind of education currently pursued is lower than the highest level attained; those reporting to attend university and are aged lower than 18; and observations where there is no continuity between the level of highest education attained and the one currently pursued. Table A1 in the appendix shows the details of the data cleaning process.

${ }^{10}$ In particular, ex-members of families might be children who left the household to start their own family (and thus are no longer considered members of the original household) or ex-spouses.
} 
which an individual is currently pursuing a level of education at least equal to not compulsory secondary education. ${ }^{11}$ As for remittances, the data source provides information on whether a family has received remittances or not. The empirical analysis uses data on remittances as reported in the 2006 survey. It is not possible to use the information on the amount of remittances households received, since this information is only available for a small fraction of the sample and it is often unreliable. Table 4 shows descriptive statistics of the variables used in the analysis for each sample and by migrant and (past) remittances status of the family.

[Table 4 around here]

As for education, Table 4 shows that members of families receiving remittances are generally characterised by a higher level of both education attained and attendance at higher education institutions. The latter is particularly high if they have a migrant abroad. Further, the education level of the other family members is generally higher in migrant households, particularly if they receive remittances. In terms of territorial distribution, those families having a migrant abroad are relatively more concentrated in non-urban areas compared to families not having a migrant abroad, suggesting a higher need for migration among households residing outside of an urban area. As for the distribution across regions, households without a migrant abroad have a relatively higher tendency to be located in Chisinau, while those with a migrant abroad are more spread out across the other regions. Further, those receiving remittances (with a migrant abroad) are relatively more concentrated in the South.

\section{Empirical Analysis}

\subsection{Endogeneity Issues, Empirical Specification, and Analysis}

The empirical analysis focuses on the estimation of the relationship between remittances and the probability of pursuing higher education, controlling and looking for the possible disruptive effect of migration. This relationship is likely to be endogenous, in particular due to the simultaneous determination of remittances and education choices. A general approach to solve this problem would be to apply instrumental variable (IV) techniques, and in the empirical literature this is often done using instruments related to the economic

11 The paper does not focus on the relationship between remittances and the probability of attending primary or compulsory secondary education, because in Moldova the school enrolment ratio for these levels of education in 2008 is around $90 \%$, while the same percentage for tertiary education is $40 \%$ (World Bank). 
conditions of the host country of the migrant, such as the unemployment rate (AmuedoDorantes and Pozo 2010; Orrenius et al. 2010). However, in the setting of the paper this strategy is problematic. In fact, the information on the host country of the migrant is available only for the part of the sample that has a migrant abroad. Using such a restricted sample does not allow estimating the relationship between remittances and education for all individuals, thus restricting the analysis to an ad hoc sample that does not make possible the analysis of the association between remittances and education, controlling for the direct effect of migration. This approach also does not allow investigating the presence of a disruptive effect of migration. Furthermore, using such a reduced sample, especially in the case of the territorial analysis, does not provide the analysis of an adequate sample size needed to consistently analyse territorial differences. Hence, instruments turn out to be weak. Due to these issues, a choice has been made to address the endogeneity issue by using past remittances in the estimations as the main independent variable. ${ }^{12}$ This choice is, in fact, able to reduce the problems of endogeneity related to the simultaneity in the determination of education and remittances choices and also allows a time lag between the receipt of remittances and the choice of pursuing a high education level. In this way, it is then possible to continue to exploit all of the sample information. In order to test for the exogeneity of past remittances with respect to education, the augmented Durbin-WuHausman test for endogeneity, suggested by Davidson and MacKinnon (1993) and used in Amuedo-Dorantes and Pozo (2010), has been applied, and results have shown the failure in rejecting the null hypothesis of exogeneity of the variable. ${ }^{13}$ Therefore, this variable is used as the main independent variable in the empirical analysis. Nonetheless, some endogeneity concerns might still apply, particularly if there are unobserved factors that

\footnotetext{
12 As a robustness check, an IV Linear Probability Model estimation has been carried out for the restricted sample (for household members with a migrant abroad). The instruments are the unemployment rate, the change in the unemployment rate with respect to the average in ten years to capture the business cycle, and the average productivity of the host country of the migrant in 2007. The test of overidentifying conditions is never rejected in these estimations. However, instruments are weak in the sample with a migrant abroad likely due to the relatively small number of observations. Results show that the impact of remittances on the probability of pursuing higher education is positive, but coefficients are inflated and not precisely estimated. These estimates are available upon request.

13 To test for exogeneity for past remittances, the instruments used are the unemployment rate in 2005 , the change in the unemployment rate over a ten-year period, and the average productivity of the host country of the migrant in 2005. The test is carried out only for the sample of the migrant, for whom this information is available, and the t-statistic associated with the residuals obtained from a first stage estimation is -1.56 , with p-value of 0.194 , which implies a failure to reject the null hypothesis of exogeneity.
} 
contemporaneously affect education and (past) remittances choices. For this reason the paper does not claim casual effects. ${ }^{14}$

In order to detect the relationship between education and remittances, a probit estimation methodology is used and the following regression is estimated:

$$
\operatorname{Pr}\left(E_{i j}=1 / H_{j}, X_{i}, R_{j}\right)=\phi\left(\alpha_{0}+\alpha_{1} H_{j}+\alpha_{2} X_{i}+\alpha_{3} R_{j}+\alpha_{4} M_{j}+\varepsilon_{i j}\right)
$$

where subscripts $i$ and $j$ refer to the individual and the household respectively. $H_{j}$ stands for a set of household characteristics such as size, number of young children, members' education level, and urban status. $X_{i}$ stands for a set of individual characteristics such as gender, age, age squared, and marital status. $R_{j}$ is the dummy variable indicating whether the individual $i$ lives in a family $j$ that receives remittances, and $E_{i j}$ is the dummy variable that takes on a value of 1 if the individual $i$ is currently pursuing a level of education at least equal to not compulsory secondary education. In the specification a migrant dummy $\left(M_{j}\right)$ indicates whether the individual belongs to a household $j$ having a migrant abroad. Table 5 shows the marginal effects of the probit estimations for the sample of reference. Robust standard errors clustered by region are presented.

Columns (1) and (2) of Table 5 show a positive and significant association between remittances and attendance at a higher education institution. In particular, and after controlling for individual and family characteristics, the probability of pursuing a high level of education is 5.4 percentage points greater for members belonging to a family receiving remittances compared to those who do not. As for the direct effect of migration, having a migrant abroad has a negligible and not significant correlation with the likelihood of pursuing higher education. This points to a lack of evidence of family disruptive forces at work due to the migration status, in contrast to McKenzie and Rapoport (2006) and Amuedo-Dorantes and Pozo (2010). The reason for this difference might lie in the nature of migration, which in the case of Moldova is prevalently temporary. Also, perhaps a disruptive effect arises for other age groups, such as very young household members below the age of $15 .{ }^{15}$ Considering the urban area of residence of the families, households

${ }^{14}$ An additional issue might also be the migrants' household self-selection, which can bias the estimates. This can arise because households choose to engage in migration. It is likely that migrants' households differ from non-migrants' households in terms of observable and unobservable characteristics. The reader has to bear in mind that these concerns might apply also to this investigation, even if the prevalence of temporary migration likely alleviates this issue.

${ }^{15}$ It might be argued that considering in the migrant sample those migrants who returned in 2007 and 2008 affect the estimation of a disruptive effect of migration. For this reason, an estimation has been carried out excluding these observations and results do not change. Still, the coefficient for the migrant dummy is low and not significant. Also, to further check this outcome, the estimation 
living in urban areas have a higher likelihood (12.7 percentage points) of attending higher education institutions. ${ }^{16}$

Column (3) of Table 5 tests the possibility of the presence of an interaction effect between the migrant dummy and remittances. It can be noted that estimates are not significant and are low in magnitude. Nonetheless, household members with a migrant abroad seem to have a slightly higher likelihood of pursuing higher education, while the positive interaction with remittances suggests a stronger association between remittances and education in migrant households. ${ }^{17}$

[Table 5 around here]

\subsection{Regional Analysis}

Up to now the results of the analysis have shown a positive and significant association between remittances and higher education of household members in Moldova. Also, living in an urban area is associated with an increase in the probability of pursuing a high level of education. The aim of this section is to gain deeper insights into the relationship between remittances and education by exploring its possible heterogeneity across Moldovan

presented in column (2) of Table 5 has been performed with the exclusion of the remittance dummy in order to assess the direct effect of migration on higher education, regardless of any influence of remittances. Results show that the coefficient estimate for the migrant dummy is higher in magnitude, but still not significant, thus confirming the lack of evidence of a significant family disruptive effect of migration for the sample considered. These estimates are available upon request.

${ }_{16}$ As for the other characteristics, results are as follows. Being female increases the probability of pursuing higher education, while being married to a Moldovan spouse or cohabiting reduces this probability. The size of the household has a negative and significant impact on education, while the number of children less than 5 years old does not represent a significant disincentive to pursue further education. The education level of the household head and spouse entail a positive and significant effect on the probability of attending a higher education institution.

17 The analysis also looked at possible differential associations between remittances and higher education across the following dimensions: gender, destination country of the migrant, and the migrant's role within the household. Estimated coefficients are generally not significant. Nonetheless, they suggest that females have a higher probability of pursuing higher education than males, but the interaction with remittances is negative, pointing to a weaker association between remittances and higher education for females with respect to males. As for the destination country of migrants, it seems that household members whose migrants are located in Eastern Europe/Russia generally have a lower probability of pursuing a higher level of education compared to both household members with a migrant abroad located in Western Europe or with no migrant abroad. Nonetheless, the interaction with remittances shows a stronger correlation between remittances and higher education for those household members with a migrant abroad located in Eastern Europe/Russia compared to the other households. Finally, when considering who has migrated within the family, it can be noted that for those with a migrant who is the household head, the likelihood of pursuing further education is higher, while a negative impact is uncovered for families whose migrants are not the household head or spouse. Also, interactions point to a weaker association between remittances and higher education when the migrant is the household head and a stronger one when the migrant is the spouse. These estimates are available upon request. 
regions. Section 2 points out that Moldova's regions are heterogeneous in terms of population density, labour market conditions, urban area prevalence, economic activity distribution, and migration patterns. Therefore, the main target of this section is to investigate whether the detected relationship between education and remittances changes according to the region in which families are settled and to identify regional characteristics that might be driving such differences. Also, the aim is to explore the possible presence of an interaction mechanism between remittances and the urban residence of the families in order to understand whether the positive association between remittances and education can be amplified for households residing in urban areas.

The analysis performs probit estimates of the relationship between past remittances and higher education, introducing additive and multiplicative dummies by region or urban status. Table 6 presents these results. Robust standard errors clustered by region are presented.

[Table 6 around here]

Column (1) of Table 6 shows probit estimates including additive regional dummies. The results show that the probability of attending higher education institutions differs across regions. In particular, Chisinau shows the highest likelihood of pursuing higher education. The other regions are characterised by a probability of 9 (Centre), 11 (North), and 20 (South) percentage points less of pursuing higher education. Gagauzia presents a similar degree of enrolment in higher education with respect to Chisinau, since the difference in the probability of pursuing higher education between Chisinau and Gagauzia is only of 4 percentage points. The fact that Chisinau has such a high percentage of young members enrolling in higher education is probably related to the higher supply of high education institutions in this city compared to the rest of the country.

Column (2) of Table 6 shows probit estimates with additive and multiplicative regional dummies. The results show other interesting insights. First, the estimations of the area dummies (basic effect) slightly change, reducing the gap in higher education with respect to Chisinau for the North, Centre, and South, while increasing for Gagauzia. Second, the interaction terms are negative and significant, except for those of Gagauzia. ${ }^{18}$ This means that the association between remittances and higher education is not homogeneous across regions. In particular, the highest associations are uncovered for Gagauzia, Chisinau, and to a slightly lesser extent the North ( -3 percentage points compared to Chisinau). In the

${ }^{18}$ However, estimates for Gagauzia have to be considered with caution due to the small number of observations in the area (66). 
Centre and the South these associations are much weaker, since the differences with respect to Chisinau are of 11 and 7 percentage points respectively. The latter outcome seems to suggest that remittances in these regions are more often used to buy other benefits compared to the rest of the country. Finally, column (3) shows the result of the interaction between remittances and the dummy related to the urban area of residence of households. It is possible to see that even if the probability of attending a higher education institution is higher in urban areas, remittances in urban areas are not correlated to higher education to a different extent than in non-urban areas. In fact, the coefficient is not significant and small (1.3 percentage points).

On the whole, these results point out different mechanisms at work in the different regions of Moldova. Indeed, while in general education levels are higher in Chisinau and to a lesser extent in the Centre and the North, education levels are significantly lower in the South. Moreover, the interaction with remittances shows that in Chisinau and the North remittances are strongly associated with higher education, while lower associations are found in the South and the Centre. These findings might be explained by considering the level of development and the pattern of migration of Moldova's regions. More specifically, they seem to suggest a complementarity of regional economic performance and migration patterns with the education level and remittances-education relationship. In fact, Chisinau is the region with the highest level of attendance at higher education institutions and shows one of the strongest associations between remittances and higher education. This city is characterised by a high level of development, good labour market conditions, and migration patterns directed toward both Western Europe and Eastern Europe/Russia. Similar results have been found for the North, a region that is also quite developed and urbanised, but with migration more directed toward Eastern Europe and Russia, compared to Chisinau.

For the Centre the pattern is more mixed. On one hand, the percentage of people pursuing higher education is relatively high; on the other hand, the association between remittances and higher education is weak compared to the other regions. This outcome also seems to reflect the characteristics of the region. In fact, similar to the North, the Centre is quite developed, with good labour market conditions and migration patterns mostly directed toward Eastern Europe and Russia. Nonetheless, it is also characterised by a large non-urban population (once excluding Chisinau), which might suggest that remittances are likely used to buy benefits different from education. The South shows the lowest probability of pursuing higher education and one of the weakest associations between remittances and education. This is the least developed region with the worst labour market conditions, a large non-urban population, and migration patterns mostly directed toward 
Russia and Eastern Europe. Hence, remittances in this region are likely used to buy essential goods rather than higher education. Finally, Gagauzia is a case apart due to its history and its medium level of development. Here, the percentage of young members attending higher education institutions is similar to the North and the Centre, but remittances seem to be strongly associated with higher education.

\section{Conclusions}

This paper looks at the relationship between remittances and higher education among young household members in Moldova. The aim of the paper is twofold. On one hand, it investigates the association between education and remittances by taking into account the possibility of a direct negative impact of migration on education (family disruptive effect) in Moldova, a country where migration is generally more temporary in nature. On the other hand, it investigates the likely heterogeneity across regions of this relationship.

The analysis makes use of past remittances in order to reduce possible endogeneity issues. Nonetheless, unobserved factors might affect the empirical results and therefore the paper does not describe the findings as casual effects. Given these premises, the empirical analysis has shown that living in a family receiving remittances is associated with a 5.4 percentage point increase in the probability that young members will attend a higher education institution. Also, the investigation has not uncovered any significant presence of a negative direct effect of migration, in contrast with Amuedo-Dorantes and Pozo (2010). This outcome might be due to the prevalence of temporary migration in Moldova, which mitigates the negative effect of migration on education, or to the fact that, if any, the disruptive effect might be effective for younger age groups. In any case, this outcome might suggest pointing to policies aimed at fostering temporary migration, thanks to this limited negative effect of migration on families in origin countries. Moreover, temporary migration can be useful to both fulfil the demand for labour in host countries and to bring back to origin countries the human capital acquired in foreign countries, while at the same time limiting brain drain due to migration.

The analysis of the relationship between remittances and higher education across regions has also pointed out interesting results. In fact, findings have shown the relevance of taking into account the regional dimension, since the relationship between remittances and higher education varies according to the region of residence of the families. In particular, the results reveal heterogeneity, both in the probability of attending higher education institutions across regions and in the association between remittances and education. As for the first, it is shown that in Chisinau and in the most developed regions 
there is a high probability that young members will pursue higher education. As for the higher education-remittances relationship, stronger associations have been found for Chisinau and the most developed regions. For the South, the association is significantly weaker. These findings suggest a possible complementarity between the remittanceseducation relationship, the economic performance of the regions, and the regional migration pattern. This might suggest pursuing policies aimed at stimulating both remittances and the development of regions in order to better exploit the likely positive effects of this source of income on education. Also, the obtained results further advocate for the need to take into account the regional dimension in investigations of the impact of remittances on other countries that, similar to Moldova, are characterised by substantial territorial heterogeneity. 


\section{References}

Amuedo-Dorantes C, Pozo S (2010) Accounting for Remittances and Migration Effects on Children's Schooling. World Development 38: 1747-1759.

Bansak C, Chesum B (2009) How Do Remittances Affect Human Capital Formation of School-Age Boys and Girls?. The American Economic Review 99: 145-148.

Calero C, Bedi A S, Sparrow R (2009) Remittances, Liquidity Constraints and Human Capital Investments in Ecuador. World Development 37:1143-1154.

Davidson R, MacKinnon J G (1993) Estimation and Inference in Econometrics, New York, Oxford University Press.

Edwards A C, Ureta M (2003) International migration, remittances and schooling: evidence from El Salvador. Journal of Development Economics 72:429-461.

Hanson G, Woodruff C (2003) Emigration and Educational Attainment in Mexico. International Migration Review 36:746-765.

Kanaiapuni S M, Donato K M (1999) Migradollars and Mortality: The Effects of Migration on Infant Mortality in Mexico. Demography 36: 339-353.

Lopez-Cordova E (2005) Globalization, migration and development: the role of Mexican migrant remittances. Journal of the Latin American and Caribbean Economic Association 6:217-256.

Lücke M, Omar Mahmoud T, Pinger (2007) Patterns and Trends of Migration and Remittances in Moldova, International Organization for Migration (IOM) report.

$\begin{array}{rrrrrrrr}\text { Lücke M, } & \text { Omar } & \text { Mahmoud } & \mathrm{T} \text {, } & \text { Steinmayr A } & \text { (2009) } & \text { Labor } & \text { Migration and } \\ \text { Remittances } & \text { in } & \text { Moldova: } & \text { Is } & \text { the } & \text { Boom } & \text { Over?, } & \text { International }\end{array}$

Organization for Migration (IOM) report.

Mansour W, Chaaban J, Litchfield J (2011) The Impact of Migrant Remittances on School Attendance and Education Attainment: Evidence from Jordan. International Migration Review 45: 812-851.

Marchetti-Mercer M.C., (2012), “Those Easily Forgotten: The Impact of Emigration on Those Left Behind”, Family Process 51(3): 376-390.

Mc Kenzie D C, Rapoport H (2006) Migration and education inequality in rural Mexico, INTAL-ITD, Working Paper No.23, Inter-American Development Bank, Washington, DC.

Pinger P R (2010) Come Back or Stay? Spend Here or There? Temporary versus Permanent Migration and Remittance Patterns in the Republic of Moldova. International Migration 48: 142-173.

Piracha M, Saraogi A (2012) The Determinants of Remittances: Evidence for Moldova. Oxford Development Studies 40: 467-491.

Piracha M, Saraogi A (2015) Remittances and Migration Intentions of the Left-Behind. Migration and Development, forthcoming. doi: 10.1080/21632324.2015.1129691.

Orrenius P M, Zavodny M, Canas Z., Coronado L (2010) Do Remittances Boost Economic Development? Evidence from Mexican States. Law and Business Review of the Americas 16: 803-822.

Siegel M, Lücke M (2013) Migrant Transnationalism and the Choice of Transfer Channels for Remittances: The Case of Moldova. Global Networks 13: 120-141.

Zhunio M C , Vishwasrao S, Chiang E.P. (2012) The influence of remittances on education and health outcomes: a cross country study. Applied Economics 44: 4605-4616.

World Bank. Indicators online: http:// data.worldbank.org/indicator. 


\section{Tables and Figures}

\section{Figure 1: Territorial Distribution in Moldova}

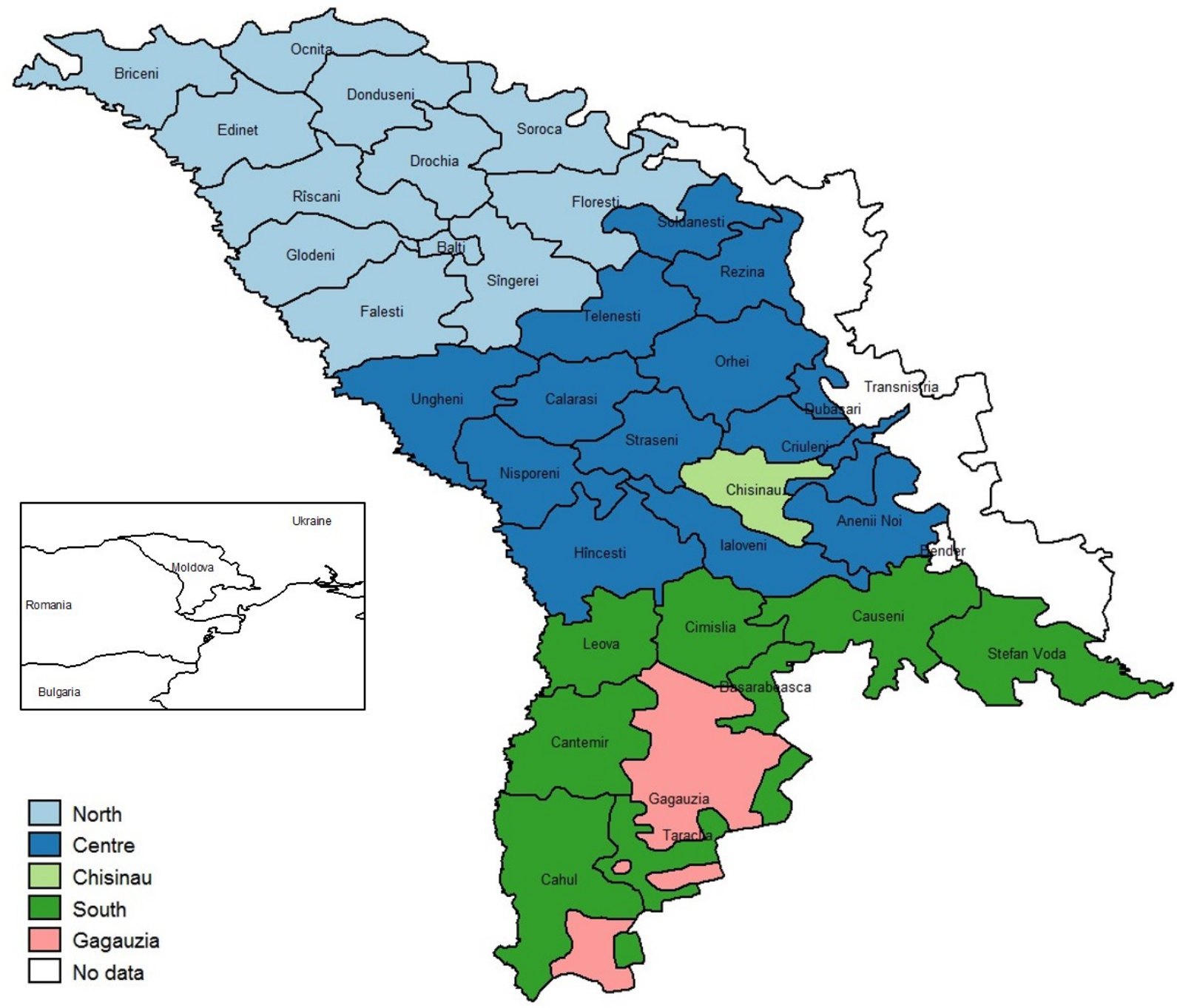

Source: Own elaboration using data from GADM (www.gadm.org). 
Table 1: Descriptive Statistics on Moldova (2011)

\begin{tabular}{lrrrrrr}
\hline Region & Population & \multicolumn{1}{c}{ Urban } & \% Urban & $\begin{array}{c}\text { Density (inhabitants } \\
\text { per square km) }\end{array}$ & Gross monthly wage (Lei) & Employment rate (\%) \\
\hline Chisinau & 789,534 & 719,593 & 91.14 & $1,381.1$ & $3,632.8$ & 4.8 \\
North & $1,006,622$ & 355,981 & 35.36 & 100.5 & $2,607.0$ & 37 \\
Centre & $1,062,848$ & 205,251 & 19.31 & 100 & $2,488.5$ & 37.6 \\
South & 540,756 & 136,163 & 25.18 & 73.3 & $2,328.0$ & 34.7 \\
Gagauzia & 160,670 & 64,708 & 40.27 & 86.9 & $2,309.0$ & - \\
\hline Total & $3,560,430$ & $1,481,696$ & 41.62 & 117.3 & $3,042.2$ \\
\hline \hline
\end{tabular}

Source: Biroul Național de Statistică al Republicii Moldova. STATISTICA TERITORIALĂ 2013. 
Table 2: Total Employees and Percentage of Employees per Economic Activity (2011)

\begin{tabular}{|c|c|c|c|c|c|c|c|c|c|c|c|c|c|}
\hline Region & Employees & Agriculture & Manufacturing. & Construction & Retail & Hotels & Transport & Finance & Real estate & Public Admin. & Education & Health & Other services \\
\hline Chisinau & 347,734 & 1.08 & 16.57 & 5.11 & 20.07 & 3.00 & 9.81 & 3.43 & 12.89 & 5.71 & 9.99 & 7.48 & 4.86 \\
\hline North & 157,492 & 15.52 & 18.32 & 2.58 & 11.24 & 1.30 & 6.63 & 1.51 & 2.90 & 6.36 & 19.75 & 10.84 & 3.05 \\
\hline Centre & 126,449 & 11.61 & 16.85 & 2.82 & 11.06 & 0.94 & 5.24 & 1.42 & 2.69 & 7.80 & 25.24 & 10.83 & 3.52 \\
\hline South & 73,171 & 18.20 & 12.13 & 2.17 & 8.95 & 0.49 & 7.25 & 1.48 & 2.14 & 8.09 & 25.56 & 9.86 & 3.69 \\
\hline Gagauzia & 27,756 & 14.16 & 22.38 & 2.91 & 11.87 & 0.79 & 2.97 & 1.62 & 3.86 & 5.35 & 21.61 & 9.24 & 3.25 \\
\hline Total & 736,780 & 8.16 & 16.68 & 3.77 & 15.11 & 1.93 & 7.78 & 2.39 & 7.52 & 6.96 & 16.63 & 9.03 & 4.04 \\
\hline
\end{tabular}

Source: Biroul Național de Statistică al Republicii Moldova. STATISTICA TERITORIALĂ 2013. 
Table 3: Regional Pattern of Migration

\begin{tabular}{|c|c|c|c|c|c|c|}
\hline & $\begin{array}{c}\text { Percentage of } \\
\text { Migrants } \\
\text { Households } \\
\text { (relative terms) }\end{array}$ & $\begin{array}{l}\text { Going to West } \\
\text { Europe }\end{array}$ & $\begin{array}{l}\text { Going to East } \\
\text { Europe and } \\
\text { Russia }\end{array}$ & $\begin{array}{l}\text { Going to outside } \\
\text { EU countries }\end{array}$ & $\begin{array}{c}\text { Total Number of } \\
\text { Observations }\end{array}$ & $\begin{array}{c}\text { Total Number of } \\
\text { Migrant } \\
\text { Observations }\end{array}$ \\
\hline Chisinau & 0.19 & 0.46 & 0.49 & 0.05 & 355 & 69 \\
\hline North & 0.42 & 0.16 & 0.82 & 0.02 & 444 & 185 \\
\hline Centre & 0.40 & 0.26 & 0.69 & 0.05 & 597 & 242 \\
\hline South & 0.48 & 0.24 & 0.70 & 0.06 & 366 & 177 \\
\hline Gagauzia & 0.42 & 0.00 & 0.75 & 0.25 & 66 & 28 \\
\hline Total & 0.38 & 0.24 & 0.71 & 0.05 & 1,828 & 701 \\
\hline
\end{tabular}

Source: Authors Calculations 2008 CBSAXA Moldovan Household Survey. 
Table 4: Descriptive Statistics of the Variables of the Analysis

\begin{tabular}{|c|c|c|c|c|}
\hline \multirow[t]{2}{*}{ Variable } & \multicolumn{2}{|c|}{ Migrant } & \multicolumn{2}{|c|}{ No Migrant } \\
\hline & Remittances & No Remittances & Remittances & No Remittances \\
\hline Individual characteristics: & & & & \\
\hline age & 19.08 & 19.40 & 19.69 & 19.84 \\
\hline gender (=2 females) & 1.57 & 1.55 & 1.48 & 1.50 \\
\hline education attainment & 2.74 & 2.74 & 2.81 & 2.74 \\
\hline $\begin{array}{l}\text { attendance at higher education } \\
\text { institutions (dichotomous) }\end{array}$ & 0.57 & 0.46 & 0.52 & 0.49 \\
\hline marital status: & & & & \\
\hline - single & 0.83 & 0.78 & 0.81 & 0.83 \\
\hline - married with spouse from RM & 0.15 & 0.19 & 0.18 & 0.15 \\
\hline - married with foreign spouse & 0.003 & 0.005 & 0 & 0.002 \\
\hline - widow & 0.003 & 0.003 & 0.005 & 0.001 \\
\hline - separate/divorced & 0.003 & 0.005 & 0 & 0.007 \\
\hline - cohabiting & 0.009 & 0.008 & 0.005 & 0.007 \\
\hline Household characteristics: & & & & \\
\hline - Composition & & & & \\
\hline size of the household & 5.08 & 5.25 & 4.77 & 4.55 \\
\hline n.child < 5 years old & 0.19 & 0.29 & 0.23 & 0.19 \\
\hline - Education & & & & \\
\hline education level household head & 2.89 & 2.84 & 2.86 & 2.86 \\
\hline education level household spouse & 2.58 & 2.55 & 2.35 & 2.37 \\
\hline education level migrant & 2.06 & 2.03 & - & - \\
\hline - Location & & & & \\
\hline Urban & 0.16 & 0.15 & 0.33 & 0.37 \\
\hline Chisinau & 8.39 & 11.08 & 16.75 & 27.20 \\
\hline North & 21.43 & 30.61 & 24.37 & 22.69 \\
\hline Centre & 30.75 & 37.73 & 41.12 & 29.46 \\
\hline South & 33.54 & 18.21 & 14.21 & 17.31 \\
\hline Gagauzia & 5.90 & 2.37 & 3.55 & 3.33 \\
\hline Observations & 322 & 379 & 197 & 930 \\
\hline
\end{tabular}

Source: 2006-2008 CBSAXA Moldovan Household Survey. 
Table 5: Probit Estimates of the Impact of Past Remittances on the Probability of Pursuing Higher Education and Interaction with Migrant Role in the Family. Marginal Effects

(1)

Past Remittances
Migrant Dummy
Past Remittances*Migrant Dumm
Female Dummy
Age
Age squared
Married with spouse from RM
Married with foreign spouse
Widow
Saparate/Divorced
Cohabiting

Size of the household

N. Children $<5$

Education household head

Education household spouse

Urban Dummy

\section{$0.069^{* * *}$}

[0.021]

$(0.021]$

\section{(2)}

(3)

$\begin{array}{cc}0.054^{* *} & 0.049 \\ {[0.027]} & {[0.039]} \\ 0.007 & 0.004 \\ {[0.012]} & {[0.016]} \\ & 0.009 \\ & {[0.035]} \\ 0.117^{* * *} & 0.117^{* * *} \\ {[0.014]} & {[0.014]} \\ 0.158^{* * *} & 0.158^{* * *} \\ {[0.036]} & {[0.036]} \\ -0.005^{* * *} & -0.005^{* * *} \\ {[0.001]} & {[0.001]} \\ -0.286^{* * *} & -0.286^{* * *} \\ {[0.087]} & {[0.088]}\end{array}$

$-0.074$

$-0.074$

[0.151]

$-0.116$

[0.203]

$-0.187$

[0.210]

$-0.314^{* * *}$

[0.089]

$-0.022^{* * *}$

[0.008]

$-0.054$

[0.037]

$0.047^{* * *}$

[0.004]

$0.039^{* * *}$

[0.007]

$0.127^{* * *}$

[0.044]

1,828

1,828

Observations

1,828

Standard errors clustered by area in brackets. ${ }^{* * *},{ }^{* *}$ and ${ }^{*}$ denote significance at the $1 \%, 5 \%$ and $10 \%$ level respectively. 
Table 6: Probit Estimates of the Impact of Past Remittances on the Probability of Pursuing Higher Education and Interaction with Area and Urban Dummy. Reference Category for Regional Dimension: Chisinau. Marginal Effects

(1)

\begin{tabular}{|c|c|c|c|}
\hline \multirow[t]{2}{*}{ Past Remittances } & $0.064^{* *}$ & $0.123^{* * *}$ & $0.051^{* *}$ \\
\hline & {$[0.026]$} & {$[0.011]$} & [0.023] \\
\hline \multirow[t]{2}{*}{ North Dummy } & $-0.112^{* * *}$ & $-0.104^{* * *}$ & \\
\hline & {$[0.008]$} & {$[0.011]$} & \\
\hline \multirow[t]{2}{*}{ Centre Dummy } & $-0.095^{* * *}$ & $-0.062^{* * *}$ & \\
\hline & {$[0.007]$} & {$[0.013]$} & \\
\hline \multirow[t]{2}{*}{ South Dummy } & $-0.203^{* * *}$ & $-0.185^{\star * *}$ & \\
\hline & {$[0.007]$} & {$[0.011]$} & \\
\hline \multirow[t]{2}{*}{ Gagauzia Dummy } & $-0.039^{* * *}$ & $-0.084^{* * *}$ & \\
\hline & {$[0.006]$} & {$[0.012]$} & \\
\hline \multirow[t]{2}{*}{ Urban Dummy } & $0.081^{* * *}$ & $0.090^{* * *}$ & $0.124^{* *}$ \\
\hline & {$[0.020]$} & {$[0.020]$} & [0.051] \\
\hline \multirow[t]{2}{*}{ Past remittances * North Dummy } & & $-0.032^{*}$ & \\
\hline & & {$[0.016]$} & \\
\hline \multirow[t]{2}{*}{ Past remittances * Centre Dummy } & & $-0.114^{* * *}$ & \\
\hline & & {$[0.009]$} & \\
\hline \multirow[t]{2}{*}{ Past remittances * South Dummy } & & $-0.068^{* * *}$ & \\
\hline & & {$[0.009]$} & \\
\hline \multirow[t]{2}{*}{ Past remittances * Gagauzia Dummy } & & $0.103^{* * *}$ & \\
\hline & & {$[0.022]$} & \\
\hline \multirow[t]{2}{*}{ Past remittances * Urban Dummy } & & & 0.013 \\
\hline & & & [0.065] \\
\hline \multirow[t]{2}{*}{ Migrant Dummy } & 0.016 & 0.014 & 0.007 \\
\hline & {$[0.014]$} & {$[0.016]$} & [0.011] \\
\hline Observations & 1,828 & 1,828 & 1,828 \\
\hline
\end{tabular}




\section{Appendix}

Table A1: Data cleaning

Deleted Obs. Remaining Obs.

\section{Exclusion Criteria}

Missing education information

Missing past remittances/migrant information

Education pursued lower than the highest completed

Attending university and lower than 18

Skipping one level of education (attaining a level>completed +1 )

Adults (>26) or very young $(<15)$

Young members who are themselves migrants

Missing observation in other covariates

14,784

2,182

12,602

881

11,721

1,665

10,056

6

10,050

140

9,910

7,693

2,217

385

1,832

4

1,828 